\title{
Can a Timeless God Act in the World?
}

\author{
Dean Lubin \\ Leyton Sixth Form College, London, UK \\ Email: Dean.Lubin@leyton.ac.uk
}

Received 27 August 2015; accepted 14 February 2016; published 17 February 2016

Copyright (C) 2016 by author and Scientific Research Publishing Inc.

This work is licensed under the Creative Commons Attribution International License (CC BY). http://creativecommons.org/licenses/by/4.0/

(c) (i) Open Access

\begin{abstract}
Can a timeless God act in the world? The purpose of this paper is to address this question by exploring the nature of timeless God's omniscience. In the first part I argue-having explored what it means to say that God is timeless-that we should think of a timeless God's omniscience factually rather than propositionally i.e. that a timeless God doesn't know all propositions, but does know all facts. One consequence of this view is that though everything (what we call past, present and future) is equally present in the mind of a timeless God, being timeless he doesn't know which events are past, which are present and which are future. For example, he doesn't know that what is presently happening in the world is presently happening. The central issue I then consider in the second part is whether his knowledge could really be of the right kind for him to act in the temporal world. I argue that though God has knowledge of all the events in the temporal world and even knows (perhaps) their temporal orderings, he is unable to intervene because to do so he would need to have the knowledge he lacks; namely, he would need to know which events in the temporal world are past, which are present and which are future.
\end{abstract}

\section{Keywords}

Timeless God, Omniscience, God's Actions, Omnipotence, The Problem of Evil

\section{Introduction}

There are two main views about how God relates to time. One is that he is in time but is everlasting; the other is that he is timeless i.e. outside time. In this paper, I am going to assume at the outset that God is timeless rather than everlasting. The question I want to address is whether a timeless God can act in the world.

This important question could be addressed in a number of different ways. We could, for example, address it from a theological perspective and consider whether there are good theological reasons (e.g. reasons based on scripture) for thinking that God (assuming he's timeless) can act in the world. Another way to address the question would perhaps be more philosophical. In particular, we could consider whether there are any metaphysical problems with the notion a timeless being acting in a temporal world. These problems might, for example, be 
analogous to the familiar problem of interaction in the philosophy of mind regarding how something non-spatial can affect (or be affected by) something with spatial extension. Each of these very different perspectives is interesting and important; but neither will be explored in what follows. Rather, I will be addressing the issue of whether a timeless God can act in the world from an entirely different epistemological perspective. My aim is to investigate the knowledge that we can reasonably attribute to a timeless God, with a view to asking whether this knowledge is of the right kind for God to be able to act in the temporal world.

In the first part of this paper, I explore what it means to say that God is timeless, and that a timeless God is omniscient. I enter a debate between A. N. Prior and Nelson Pike regarding how we should understand timeless God's omniscience and in particular whether it should be understood propositionally or factually. Since there are some propositions that a timeless God cannot know—-for example, the proposition that I am now writing this abstract-I argue along with Pike (and William P. Alston) that God's omniscience should be understood in factual rather than in propositional terms: God doesn't know all propositions, but he does know all facts.

But what bearing does the view I take on timeless God's omniscience have on other aspects of his nature? For example, God is generally thought of as a being that can act in the temporal world. The question then arises as to whether thinking of timeless God's omniscience in factual terms allows us to make sense of God as a being that can intervene in this way. Neither Prior nor Pike seems to consider this issue (at least, not in the papers I consider). To this end, in the second part of this paper I specifically consider whether the factual omniscience of a timeless God is such that he can act in the temporal world. I argue that a timeless God is unable to intervene in the world because-though he knows all the events in the world and knows (perhaps) their temporal orderings-being timeless, he lacks knowledge (knowledge which I argue he would need if he is to be an intervening God) of which events are past, which are present and which are future.

\section{God's Timelessness}

Let's begin by considering some aspects of God as a timeless being. As a timeless being, he certainly has neither temporal location nor temporal extension. But how does he relate to events that do have temporal location and extension? In particular, how can we understand his awareness of events of this kind?

As a timeless being, God's awareness of these events is not—cannot be-in time: it's the events that are in time, not the awareness. For example, his awareness of the London Paralympics, or of the London Olympics, cannot be in time. Moreover, though the London Paralympics took place after the London Olympics, his awareness of the Paralympics cannot be after his awareness of the Olympics. Indeed, there can be no temporal distinction between these different states of awareness. (This doesn't mean that the time at which he is aware of the London Olympics is the same as that at which he is aware of the London Paralympics. Being timeless, there is no time at which he is aware of these events. When trying to understand God's timelessness, we shouldn't appeal to the notion of simultaneity.)

Further, and relatedly, as time passes things change in the temporal world-the Olympics end and the Paralympics begin — but what God as a timeless being is aware of doesn't change. (After all, if what God was aware of did change, he would surely have to be in time.)

These thoughts might lead us away from talking about God's different states of awareness of temporal events. Instead, we might talk about his single state of awareness - a single state of awareness of everything (i.e. of all temporal events: past, present and future).

We can illustrate a timeless God's awareness of events in the temporal world by adapting a picture given to us by Augustine. Imagine a person walking on a road that leads past a mountain. To that person, at one time it will appear that she is at one point; and at another (later) time it will appear that she is at another (further along the road). This is because she is in time, so to her some things are in the past, others are in the present, whilst others are in the future. By contrast, God as a timeless being is like an observer on the top of the mountain looking down on the road. What he sees when he looks down on the road-of-time is all of these times (and so all the different spatial positions she occupies as time passes). All of these are equally in his mind.

\section{Timeless God's Omniscience}

Having briefly considered some important aspects of God's timelessness, let's consider now the relationship between God's timelessness and his omniscience.

In "The Formalities of Omniscience", A. N. Prior calls into question the compatibility of God's timelessness 
and his omniscience. His basic claim is that there are some truths about the world that a timeless being couldn't know; and that an omniscient being couldn't therefore be timeless. He supports this claim in the following way:

\begin{abstract}
"In this statement that for every $\mathrm{p}$, if $\mathrm{p}$ then God knows that $\mathrm{p}$, are we to understand this verb 'knows' as a verb in the present tense, or are we not? Many very reputable philosophers, e.g. St Thomas Aquinas, have held that God's knowledge is in some way right outside of time, in which case presumably the verb 'knows' in our translation would have to be thought of as tenseless. I want to argue against this view, on the ground that its final effect is to restrict what God knows to those truths, if any, which are themselves timeless. For example, God could not, on view I am considering, know that the 1960 final examinations at Manchester are now over; for this isn't something that He or anyone could know timelessly, because it just isn't true timelessly. (It's true now, but it wasn't true a year ago (I write this on August 29 $\left.9^{\text {th }}, 1960\right) \ldots$ )... (Prior, 1962: p. 116).
\end{abstract}

Another example might be that a timeless being couldn't know that the London Olympics and Paralympics have finished. After all, a timeless being cannot know that this event is a past event; only a temporally located being can know this. As a consequence, there are some truths about the world (as Prior would put it, truths that aren't timelessly true) that a timeless God cannot know.

On this view, a timeless God's knowledge seems to be seriously limited. If it follows from this that God isn't omniscient, then perhaps we should agree with Prior that this calls God's timelessness into question. But, as we shall see, whether this does follow depends on how we understand the notion of omniscience.

Some philosophers have responded to Prior's argument by appealing to the distinction between statements (or propositions) on the one hand, and facts on the other. This approach is adopted by Nelson Pike in "God and Timelessness”:

"A timeless individual could not have an item of knowledge that he could formulate or report in a statement such as, "The first scene is now on the screen" or "Today is the twelfth of May". ... I cannot see, however, that this observation gives warrant for the claim that there is something that a timeless individual could not know. ... we have not been given a reason for thinking that the facts in question could not be reported by a timeless being in statements free of temporal indexical expressions.” (Pike, 1970: pp. 94-95).

At the centre of the debate between Prior and Pike is a distinction between the following two ways in which we can understand God's omniscience:

1) To be omniscient is to know all true propositions.

2) To be omniscient is to know all facts.

If we adopt 1), then we will be forced to say that a timeless God isn't omniscient. After all, a timeless God doesn't know that the London Olympics have finished; and so there is a proposition he doesn't know. However-following Pike's line of thought-if we adopt 2) we may not have to do this. A timeless being couldn't know that the London Olympics have finished; but can know that the London Olympics begin in July 2012 and can know that they end by August 2012. Although the proposition that the London Olympics begin in July 2012 and end by August 2012 doesn't seem to be equivalent to the proposition that the London Olympics have finished, the facts "accessed" by means of these different propositions can be the same.

On this view, we can say that a timeless God knows every fact (so is factually omniscient) but not every proposition (so is not propositionally omniscient) since there are some propositions that can only be known by temporal beings. (We have an access to some facts which is not available to timeless God, but there aren't any facts that we know but he doesn't.)

(In deciding between 1) and 2) we should note that there is an issue about whether the temporal now, for example, is an objective feature of reality or is just a feature of our experience of reality. If the temporal now is an objective feature of reality, then we will not be able to defend timeless God's omniscience by appealing to 2). Although, I don't think that the temporal now is an objective feature of reality, I will not explore this issue here.)

One reason for rejecting 1), then, will be that adopting 2) preserves timeless God's omniscience. But a perhaps better reason - better partly because it's independent in that it doesn't appeal to the issue of timelessnesscalls into question whether God knows facts through propositions. This reason focuses on the nature of human knowledge and in particular on its apparent propositional nature. This propositional nature can be seen as a way in which we are limited: we can only know facts through propositions. But God isn't limited in this way. Instead, he is able to have direct knowledge of facts. This line of thought is explored by William P. Alston in "Does God 
Have Beliefs?”:

"It seems plausible to suppose that the propositional character of human knowledge stems from our limitations. Why is our knowledge parcelled out in separate facts? For two reasons. First, we cannot grasp any concrete whole in its full concreteness; at most we cognize certain abstract features thereof, which we proceed to formulate in distinct propositions. Second, we need to isolate separate propositions in order to relate them logically, so as to be able to extend our knowledge inferentially. Both these reasons are lacking in the divine case. God can surely grasp any concrete whole fully, not just partial aspects thereof. And God has no need to extend His knowledge, inferentially or otherwise, since it is necessarily complete anyway. Hence there would be no point in God's carving up His intuition of reality into separate propositions. We have to represent divine knowledge as the knowledge of this or that particular fact; but this is only one of the ways in which we are forced to think of God's nature and doings in terms of our own imperfect approximations thereto.” (Alston, 1989: p. 183).

Alston seems to prefer what he calls the "intuitive" conception of God's knowledge, according to which his knowledge of a fact consists in its (direct) presence to his consciousness:

“... the intuitive conception represents the fullest and most perfect realization of the cognitive ideal. ... Immediate awareness of facts is the highest form of knowledge just because it is a direct and foolproof way of mirroring the reality to be known. There is no potentially distorting medium in the way, no possibly unreliable witnesses, no fallible signs or indications. The fact known is "bodily" present in the knowledge. The state of knowledge is constituted by the presence of the fact known. This is the ideal way of "registering" a fact and assimilating it into the subject's system of cognition and action guidance. Hence this is the best way to think of God's knowledge.” (Alston, 1989: p. 190).

For the reasons given by Pike and Alston, I think we should understand God's omniscience in terms of 2) and should resist the temptation to say (along with Prior) that God isn't timeless because a timeless God wouldn't be omniscient. Rather, we should say that a timeless God is factually omniscient i.e. that he knows every fact (though not through propositions).

A timeless God is, then, (factually) omniscient. But what bearing does this view of timeless God's omniscience have on other aspects of his nature? For example, God is generally thought of as a being that can act in the temporal world. If we think of God's omniscience in factual terms does this allow us to make sense of God as a being that can intervene in this way?

\section{God's Action in the World}

Can a timeless God act in the world? I will not be considering any theological reasons (e.g. reasons based on scripture) for thinking that he can; nor any metaphysical problems there might be with the notion of a timeless being acting in a temporal world. The issue I will consider stems from the notion of God's omniscience and is therefore epistemological.

If everything (what we call past, present and future) is equally (present) in the mind of a timeless God-if there is no change in his awareness as time passes in the temporal world-then he doesn't know what's in the past, what's in the present and what's in the future. In particular, he doesn't know what is presently happening in the world; nor even who presently exists in the world. This is not to deny his omniscience. He is omniscient; but his omniscience is — as has already been argued — to be understood in factual rather than in propositional terms. The real question is whether his knowledge is the right kind of knowledge for him to be able to intervene in the world.

In considering the question of God intervening in the world, we naturally focus on acts that we think God would be motivated to perform (if he could); and this naturally leads us to think of him performing actions which prevent (serious) cases of moral or natural evil.

God timelessly knows of the genocide committed at Auschwitz. But if he doesn't know whether this is past, present or future (and if he doesn't, for example, even know whether Hitler now exists) how can he intervene to prevent it? God timelessly knows that in 1755 there is an earthquake in Lisbon. But if he doesn't know whether 1755 is past, present or future-and so doesn't know whether this earthquake has happened, is happening, or will happen-how can he intervene? 
If God is timeless and so everything-past, present and future-is equally in his mind, then past, present and future events are, for him, on a par. One view that might be taken as a result of this-if we think that in order to intervene in the temporal world God doesn't need to know which events are past, present and future-is that each is equally available to him in the sense that he is able to equally intervene in any of them. But the view that for a timeless God past, present and future events are on a par, might just as easily lead us to the view-if we think that in order to intervene God does need to know which events are past, present and future-that he cannot intervene in any of them. Which of these two contrasting views should we adopt?

For human beings, the ability to act successfully very often requires not just factual knowledge, but also a particular kind of way of knowing these facts. We need to know how we are temporally related to them-and so we need to be temporally located. To know these facts timelessly (even if we could know them in this way) wouldn't be enough. Such timeless knowledge wouldn't enable us to act.

For example, suppose that I know the winning lottery numbers for 1 January 2016. As a temporally located being, I may be able to act on that knowledge and place a winning ticket. This will depend on my knowing whether that date is in the past, present, or future. We might imagine that I have been travelling in a time machine and don't know whether the lottery draw for 1 January 2016 is in the past, present or future. I may then be unable to take advantage of my knowledge.

Generally speaking, temporally located beings need to know what events are past, present or future in order to be able to act on much of their knowledge. Of course, we usually just take this knowledge for granted and in acting aren't conscious of it; but to see that we do nevertheless need it, we simply need to consider whether we could act if - as, for example, in the time machine case-we didn't know whether particular events are in the past, present or future.

Can analogous claims be made about God? Can we say that in order to act in this temporal world, God needs to know whether particular events are in the past, present or future? If so, a timeless God who cannot know this, will not be able to act.

We can investigate this issue by reconsidering the earlier example of a person walking along the road by a mountain. A timeless God doesn't know — cannot know-her present location on the road because all of her different spatial positions (past, present and future) are equally in his mind. What he sees in his one big perception is (among very many other things) her past, present and future positions. We might imagine that a huge boulder has detached from the mountain top and is now on its way down the mountain. In the absence of any divine intervention the boulder will kill her. But there will be nothing that God can do to prevent her death if (like us) in order to act a timeless God needs to know which of her spatial positions she is occupying presently. The issue is whether he needs this knowledge in order to intervene; or whether any knowledge we can attribute to him as a timeless God-for example, his timeless knowledge that a boulder falls down the mountain and will kill her if it hits her-would be sufficient for him to act.

In order to answer these questions, we need to consider other relevant knowledge that we can attribute to a timeless God. A timeless God doesn't just timelessly know the events he sees in his perception, he also knows (at least some of) the temporal orderings of these events. For example, some events are logically temporally prior to others. John's birth is logically prior to his getting a job as an engineer; and God would therefore know the temporal ordering between these two events. Further, some events are causally temporally prior to others. Stone throwings cause window breakings and are therefore temporally prior to them. So God, knowing causal laws, knows that a particular stone throwing is temporally prior to a particular window breaking. God doesn't experience (and doesn't need to experience) such temporal orderings-he would have to be temporal for thatbut he is nevertheless aware of them. (This is not to concede that God knows the temporal orderings of all events. There may be temporal orderings that could only be known if they're experienced. If so, a timeless God couldn't know them.) How, then, could knowing the temporal ordering of events be relevant to the issue of whether a timeless God can intervene in the temporal world?

If we think that in order to intervene in the world a timeless God doesn't need to know what events are past, present and future, then we might take the view that knowledge of the temporal ordering of events is (epistemologically) sufficient for him to act. If so, he would be able to intervene by altering an event (and so altering its consequences). So, knowing the temporal ordering of events e.g. that A (the boulder falls down the mountain) precedes B (the person dies) and that B is a consequence of A, God can intervene in A in order to prevent B. But if the issue of God's knowledge of which events are past, present and future is irrelevant to whether he can intervene (in particular, if he doesn't need to know which events are present), then there can be no temporal con- 
straints on event A: A could be any event past, present or future. Thus, if A is a past or future event, the view being considered (that in order to intervene in the world a timeless God doesn't need to know what events are past, present and future) leads to the seemingly absurd view that God can alter the past; and to the view (is this any less absurd?) that he can alter the future. Indeed, the view that God can intervene in the past was famously too much for St. Jerome, and many medieval theologians, to swallow. The question then is whether the view that knowledge of the temporal orderings of events is sufficient for a timeless God to act can be rescued from these absurdities.

One rescue attempt might appeal to a distinction—stemming from a debate dating back to at least the $12^{\text {th }}$ century - between divine power being "absolute" and divine power being "ordained". On the first, absolute, view, God can intervene in the past; but on the second, ordained, view, God cannot do so at least in the sense that he somehow binds himself to intervene only in the present ${ }^{1}$ (Oakley, 1988). The rescue attempt will clearly try to appeal to the idea that divine power is ordained rather than absolute.

But exactly how could a timeless God bind himself to intervene only in the present? The ability of a timeless God to bind himself to act only in the present would require that he is able to separate out in his one big perception those events which are present from those which are past and those which are future. But in order to do this, he would need to know which events are past, present and future; and a timeless God cannot know these things. This rescue attempt is therefore doomed to failure.

To summarise, the view that knowledge of the temporal orderings of events is sufficient for a timeless God to intervene in the world seems to lead to the absurd idea that (inter alia) God can intervene in the past; and we cannot rescue this view from this absurdity by ultimately appealing — via the absolute/ordained distinction- to knowledge that could only be attributed to an everlasting God.

The view I've just rejected - that knowledge of the temporal orderings of events is sufficient for a timeless God to intervene in the world-might well be based on the assumption that a timeless God can intervene. After all, if we assume that a timeless God can intervene, then we'll think that in order to intervene God cannot need to know which events are past, present or future. Moreover, we'll think that whatever knowledge we can legitimately attribute to him is enough for him to intervene; and in particular, we'll think that knowledge of the temporal order of (some) events is somehow enough. But then (as I've just argued) we'll have no escape from the absurd view that God can intervene not only in our present, but also in our past and future.

What this shows is that it is wrong to make the initial assumption that a timeless God can intervene in the world. Instead, we should say-if we continue to think that God is timeless - that God cannot act in the world because in order to act, he would need knowledge of which events are past, present and future ${ }^{2}$.

\section{Conclusion}

In order to act in the temporal world, a timeless God would have to know which events in that world are past, which events are present, and which events are future. Since this is knowledge that a timeless God cannot have, the conclusion we should come to if we continue to think that God is timeless, is that he cannot act.

It might be thought that the fact that God doesn't intervene to prevent serious cases of moral and natural evil, is good evidence for his non-existence. But although this is perhaps evidence for the non-existence of an everlasting God; it isn't evidence for the non-existence of a timeless God, since a timeless God cannot intervene. Indeed, perhaps the best explanation of the fact that God doesn't seem to intervene to prevent serious cases of moral and natural evil, is that he is timeless and so can't!

\section{References}

Alston, W. P. (1989). “Does God Have Beliefs?” in Divine Nature and Human Language. Ithaca: Cornell University Press: 178-193.

Oakley, F. (1998). The Absolute and Ordained Power of God in Sixteenth- and Seventeenth-Century Theology. Journal of

${ }^{1}$ For more on the history of the distinction between absolute and ordained power, see Francis Oakley in "The Absolute and Ordained Power of God in Sixteenth- and Seventeenth-Century Theology” [Journal of the History of Ideas, Vol. 59, No. 3 (Jul., 1998), pp. 437-461].

${ }^{2}$ The epistemological problem considered doesn't apply to timeless God's act of creation. Indeed, this creative act cannot require knowledge of which events are past, present and future; because (on the assumption that time comes into being with the universe's creation) there are no such events unless and until the universe is created. Although a timeless God wouldn't be able to intervene in the world, this doesn't mean that he isn't omnipotent. His omnipotence needs to be understood in terms of his timelessness; and there is nothing a timeless being can do but which God cannot do. Indeed, only an omnipotent being could bring the universe into existence. 
the History of Ideas, 59, 437-461. http://dx.doi.org/10.1353/jhi.1998.0027

Pike, N. (1970). God and Timelessness. London: Routledge.

Prior, A. N. (1962). The Formalities of Omniscience. Philosophy, 37, 114-129. http://dx.doi.org/10.1017/S0031819100036780 